\title{
Effect of Rim Seal on Evaporation Loss from Khark Island Storage Tanks
}

\author{
Mahmood Farzaneh Gord, Amin Nabati*, Morteza Saadat Targhi and Alireza Rasekh \\ The Faculty of Mechanical Engineering, Shah rood University of Technology, Shah rood, Iran
}

\begin{abstract}
Evaporation loss is a natural process in which part of liquid is turning to vapor and vanishing into the atmosphere. Crude oil compound from the several hydrocarbons in which some of them evaporate and could be released into the atmosphere at ambient temperature and pressure. This process causes to pollute the environment and has effects on crude oil quality. Any reduction in the loss will also have financial benefit. This makes the phenomena, crude oil evaporation loss an important issue, which should be carefully investigated and effects of various parameters be studied.

The aim of the present work is to determine the evaporation rates from external floating storage tanks and to study the effects of rim seal type on the losses. In this study, a numerical scheme has been developed for estimating the time variations of the storage tank temperature and evaporative losses. The scheme validated against the measured values of the storage tank temperature at different times during a day, where reasonable agreements observed. Furthermore, the numerical value of monthly averaged evaporation losses also have been compared with the estimations based on the API AP-42 standard.

In this paper, seal type on the evaporation loss has bee $\mathrm{n}$ investigated and determined. Further evaporate loss from rim seals for the Khark Island storage tanks are compared. Nine types of the primary/secondary seal configurations have been studied. The results unveiled that one type of the primary/secondary seal configuration has advantages over the other configurations in preventing evaporative loss.
\end{abstract}

Keywords: Storage tank; Crude oil; Evaporation loss; Rim seal; Khark Island

\section{Introduction}

The Khark Island is main Iran oil export terminal which contains about 40 crude oil storage tanks with capacity 1 million barrels. The tanks mainly have flouting roof designs. These tanks are used to hold oil for brief periods in order to stabilize flow between production wells and transporting ships. Due to location of the Island which is in hot climate, during storage, at ambient temperature and pressure, light hydrocarbons of crude oil vaporize and assemble in the space between the liquid and roof of the tank, these vapors are often vented to the atmosphere. This process causes to pollute the environment and also has effects on crude oil quality. Any reduction in the loss will also have financial benefit. This makes the phenomena, crude oil evaporation loss, an important issue which should be carefully investigated and effects of various parameters be studied.

Design of storage tanks depends on various parameters such as the vapor pressure, storage temperature and pressure, and the toxicity of liquid [1]. The fixing-roof tanks are mainly used for petroleum materials with a vapor pressure less than 1.5 psia [2], while floatingroof tanks are used for petroleum materials with a vapor pressure of 1.12-11.5 psia [1]. An external floating roof tank typically consists of an open topped cylindrical steel shell equipped with a roof that floats on the surface of the storage liquid, which rises and falls as the liquid level changes. Floating roof tanks are equipped with a sealing system, which is attached to the roof perimeter and covers the gap between the roof and the tank wall [3]. The basic designs available for external floating roof rim seals are mechanical shoe seals, liquidmounted seals, and vapor-mounted that called primary seals [4]. A secondary seal is often used for covering the entire primary seal. The floating roof structure and the sealing system are designed to reduce evaporative losses of the petroleum materials. Evaporative losses from the external floating roof tanks are limited to the losses from the sealing system and roof fittings and any remaining liquids on the tank walls, while the floating roof falls down. There have been very limited studies related to the storage tank evaporative losses. Wongwises et al. [5] evaluated the gasoline evaporation losses from Thailand storage sites and service stations during refueling and loading. They estimated the total gasoline evaporative losses of about 21,000 tons/ year throughout the Thailand. Ramachandran [3] also investigated the underlying causes of storage thank emissions and analyzed the options of reducing them.

Asharif and Zorgani [6] calculated evaporative losses from existing large crude oil storage tanks located in a Libyan oil field and investigated the operating variables including the number of separation stages, operating temperature and pressure of each separator. They concluded that the operation variables of the existing process facilities can be adjusted in order to minimize the losses from storage tanks. Digrado and Thorp [7] compared the evaporation losses between the internal and external floating roofs. They also determined the losses associated with different sealing arrangements based on the American Petroleum Institute (API) standards $[8,9]$.

Zareie et al. [10] experimentally determined the amount of the volatile organic compounds emitted from an industrial external floating roof tank by monitoring the level of the liquid in the tank

*Corresponding author: Amin Nabati, The Faculty of Mechanical Engineering Shah rood University of Technology, Shah rood, Iran, Fax: +982733395440 E-mail: amin459@yahoo.com

Received September 20, 2010; Accepted October 25, 2010; Published Octobe 28, 2010

Citation: Gord MF, Nabati A, Targhi MS, Rasekh A (2010) Effect of Rim Seal on Evaporation Loss from Khark Island Storage Tanks. J Pet Environ Biotechnol 1:103. doi:10.4172/2157-7463.1000103

Copyright: ( 2010 Gord MF, et al. This is an open-access article distributed unde the terms of the Creative Commons Attribution License, which permits unrestricted use, distribution, and reproduction in any medium, provided the original author and source are credited. 
Citation: Gord MF, Nabati A, Targhi MS, Rasekh A (2010) Effect of Rim Seal on Evaporation Loss from Khark Island Storage Tanks. J Pet Environ Biotechnol 1:103. doi:10.4172/2157-7463.1000103

Page 2 of 7

and its temperature for a period of 35 days. They also compared their findings with the values computed based on the API standards and found out that the API predictions are slightly lower than the experimental data.

This brief review of the related literature indicates the shortage of information in the field of storage tank evaporative losses. In the present paper a numerical method has been developed for solving the energy equation to predict the storage tank temperature and to estimate the evaporative losses. More importantly, the effect of seal type on the evaporative loss has been investigated. The numerical predictions have been compared with the experimental data provided from a storage tank with the capacity of one million barrels of light crude oil located in Khark Island the main Iran oil export terminal.

\section{The Case Study}

The problem under consideration is a typical storage tank in Khark Island shown in (Figure 1). As seen in the picture, the exterior surface paint of the tank is white with two small rings of blue and yellow color indicating that the tank is suitable for storing both heavy and light crude oil.

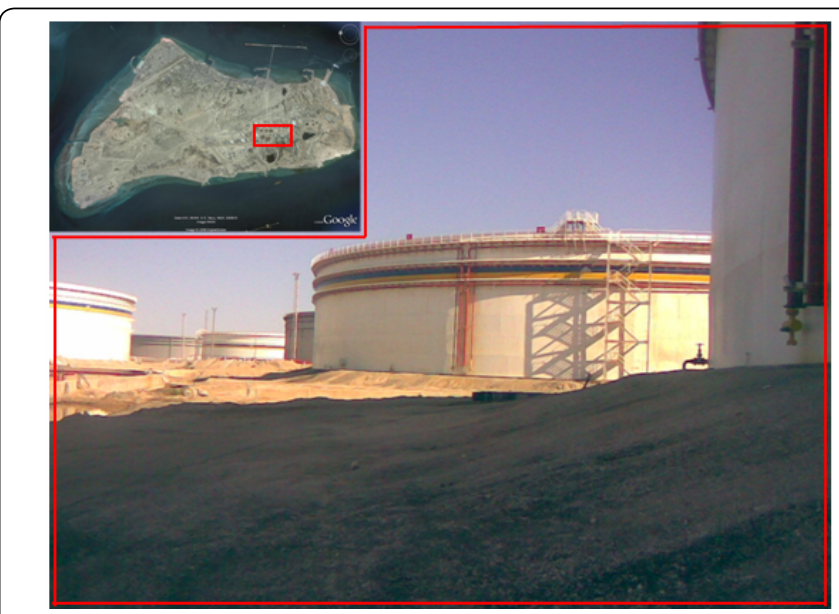

Figure 1: The oil storage tank under consideration in Khark Island.

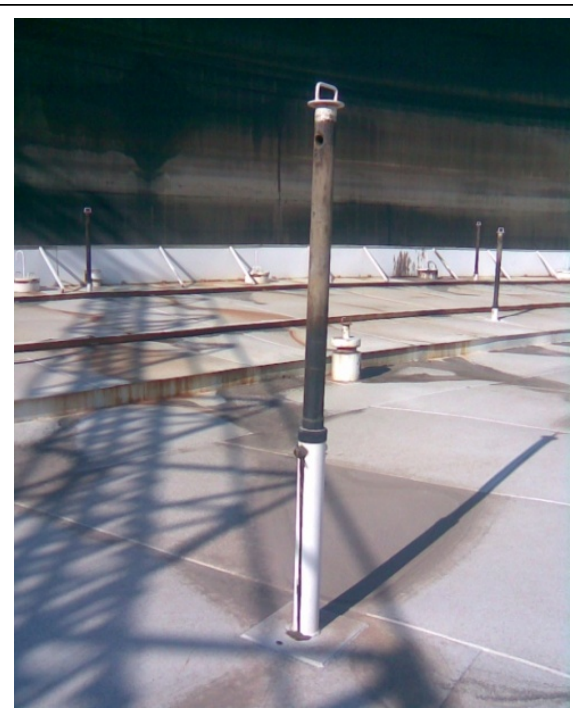

Figure 2: The deck leg of storage tank.
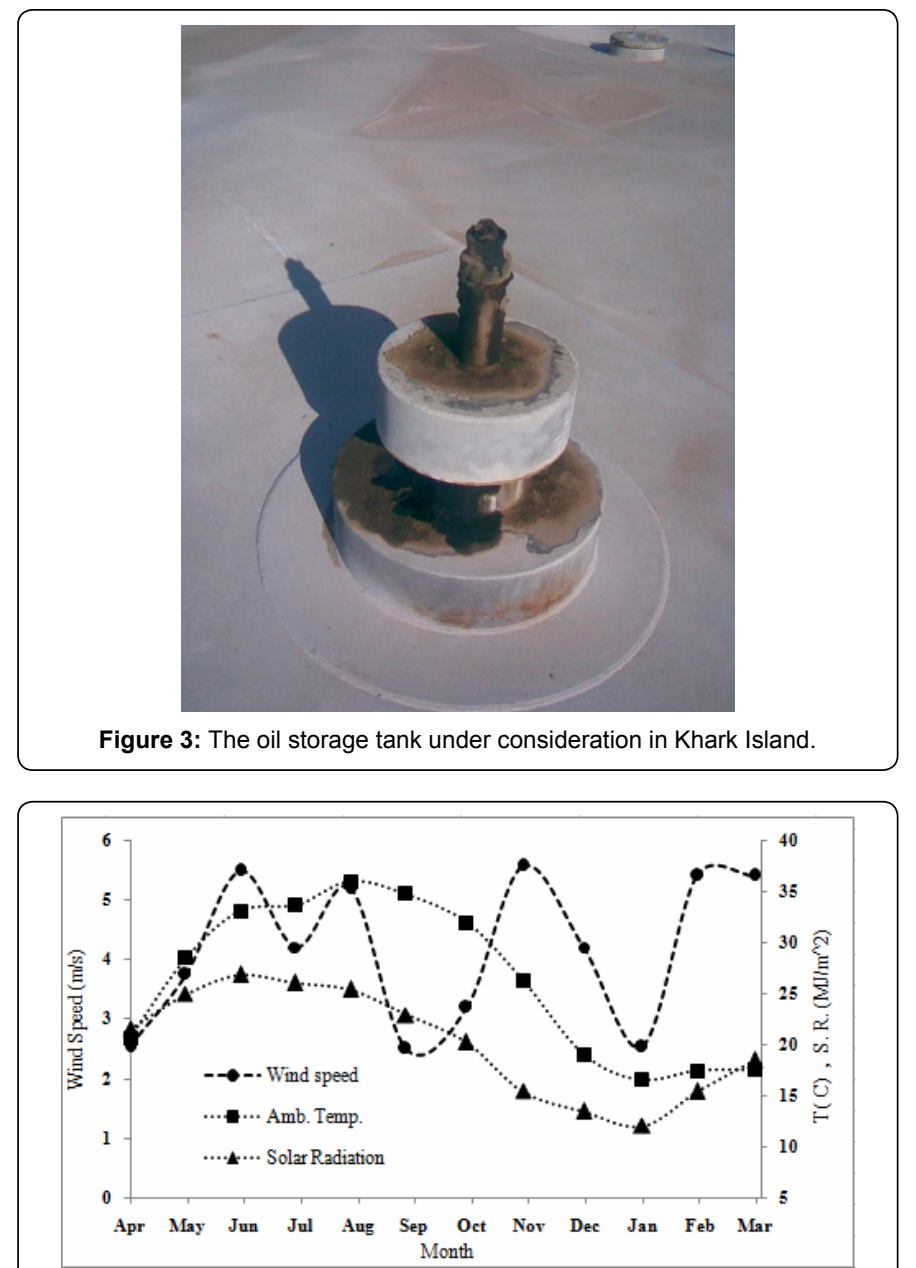

Figure 4: Solar radiation, average temperature and average wind speed for each month.

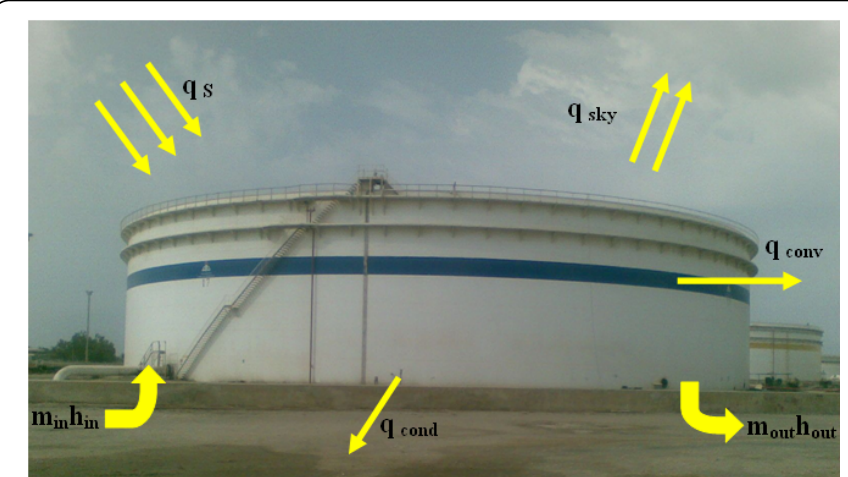

Figure 5: Schematic figure of oil storage tank with all input and output energies.

Two fitting types of the tank are shown in (Figure 2 and Figure 3). (Figure 2) show deck leg of tank, the exiting of crude oil vapor from gasketed area case to blacked the near area of gasketed, figure also show exposed liquid on the tank internal walls that vaporize as time goes on. (Figure 3) show vacuum breaker. The evaporation loss from this part lead to dirty around it, also the exiting of vapor could see in shadow of vacuum breaker.

In the study, light crude oil with API of 33.36 has been stored in the tank, where its chemical composition is given in Table 2 . The 
experiment is carried out by Iran Oil Terminal company laboratory located in Khark Island. This data has been used to calculate thermal properties of the crude oil employing the commercial software HYSYS version 3.1 (Table 1).

\section{Climate condition of the Khark Island}

Climate conditions such as ambient temperature, wind speed and solar irradiation are directly related to the evaporative losses as will be discussed later. Climate conditions have big effects on temperature of crude oil within the storage tank, this temperature have big effects on evaporative losses in crude oil storage tanks. The climatic data has been extracted from the Iran Weather Institute information for 2007. The average ambient temperature and wind speed for the 5th day of each month are shown in (Figure 4).

The solar radiation is the main cause of the evaporative losses in the floating roof tanks. For estimating solar radiation on the earth surface several engineering models have been proposed. In all of the models the weather condition and geographic location are important factors [11]. Kamali and Moradi [12] have examined various models including Angstrom, Bristow and Campbell, Hargreaves and Reddy for locations and weather conditions relevant to the present problem and compared their finding with the experimental data. It was suggested that Angstrom model with some modifications is more suitable for Khark Island conditions, and thus has also been adopted for the present study.

\begin{tabular}{|c|c|c|c|}
\hline Fitting Type & \multicolumn{2}{|c|}{ Construction Details } & Number \\
\hline Access hatch & \multicolumn{2}{|c|}{ Bolted cover, gasketed } & 3 \\
\hline Vacuum breaker & \multicolumn{2}{|c|}{ Weighted mechanical actuation, gasketed } & 14 \\
\hline Roof drain & \multicolumn{2}{|l|}{$100 \%$ open } & 5 \\
\hline Unslotted Guide Pole & \multicolumn{2}{|c|}{ Ungasketed sliding cover } & 2 \\
\hline Deck leg & \multicolumn{2}{|c|}{ Adjustable, pontoon area - gasketed } & 301 \\
\hline Rim vent & \multicolumn{2}{|c|}{ Weighted mechanical actuation, gasketed } & 13 \\
\hline \multirow[b]{2}{*}{ Rim-seal } & Primary & Liquid-mounted seal & \multirow[b]{2}{*}{1} \\
\hline & Secondary & Weather shield & \\
\hline
\end{tabular}

Table 1: Fitting types of the storage tank.

\begin{tabular}{|l|l|l|l|}
\hline Assay Liq. Volume \% & Boiling Temp (C) & Light Ends & Liq. Mass \% \\
\hline 2.08 & 15 & Methane & 0.00 \\
\hline 7.51 & 65 & Ethane & 0.00 \\
\hline 14.43 & 100 & Propane & 0.02 \\
\hline 17.42 & 125 & I-Butane & 0.06 \\
\hline 22.05 & 150 & N-Butane & 0.36 \\
\hline 26.84 & 175 & I-Pentane & 0.80 \\
\hline 31.36 & 200 & N- Pentane & 1.16 \\
\hline 35.67 & 225 & 2,2 DiMethyl Butane & 0.02 \\
\hline 40.56 & 250 & 2,3DiMethyl Butane & 0.17 \\
\hline 45.00 & 275 & 2Methyl Pentane & 0.56 \\
\hline 48.65 & 300 & 3Methyl Pentane & 0.33 \\
\hline 51.71 & 325 & N-Hexane & 0.36 \\
\hline 55.48 & 350 & Methyl Cyclo Pentane & 0.06 \\
\hline & & Benzene & 0.04 \\
\hline & & Cyclo Hexane & 0.01 \\
\hline API & 33.36 & H O & 0.00 \\
\hline RVP & 7.89 & TOTAL & 3.95 \\
\hline
\end{tabular}

Table 2: Assay data of light crude oil under consideration.

\begin{tabular}{|l|l|l|l|l|}
\hline coefficient & spring & summer & autumn & winter \\
\hline$a$ & 0.37 & 0.37 & 0.37 & 0.37 \\
\hline$b$ & 0.35 & 0.35 & 0.38 & 0.38 \\
\hline
\end{tabular}

Table 3: Coefficients that adjusted for Khark Island from Angstrom model.
Based on the Angstrom model, solar radiation, $H$, can be estimated using the following equation:

$$
\frac{\mathrm{H}}{\mathrm{H}_{\mathrm{O}}}=\mathrm{a}+\mathrm{b} \frac{\mathrm{S}}{\mathrm{S}_{\mathrm{O}}}
$$

Where $a$ and $b$ are coefficients that must be chosen according to the location and weather conditions, $S$ and $S_{0}$, are average sunshine duration and cloudless sunshine duration, respectively. Following Kamali and Moradi, [12] $a$ and $b$ for Khark Island shown in (Table 3).

The cloudless hourly global irradiation received can be calculated using the following equation:

$\mathrm{H}_{\mathrm{O}}=\frac{24 \times 3600}{\pi} \cdot \mathrm{I}_{\mathrm{SC}}\left(\frac{\overline{\mathrm{d}}}{\mathrm{d}}\right)^{2} \cdot\left[\cos \varphi \cdot \cos \delta \cdot\left(\sin \omega_{2}-\sin \omega_{1}\right)+\frac{2 \pi\left(\omega_{2}-\omega_{1}\right)}{360} \cdot \sin \varphi \cdot \sin \delta\right]$

Where $I_{s c}$ is set to $1367 \mathrm{~W} / \mathrm{m}^{2}$ according to the world radiation center [12] and $\omega$ is given by the following equation:

$$
\omega=(\mathrm{t}-12) \times 15
$$

With using earlier equations, solar radiation for the Khark Island has been calculated and is shown in (Figure 4). It can be realized that solar radiation is highest during June where ambient temperature is highest during July \& August.

\section{The Numerical Method}

\section{Energy balance of the tank}

A schematic diagram of the crude oil storage tank with all incoming and outgoing forms of energy is shown in (Figure 5).

In developing the energy balance of the tank, the oil temperature variation inside the tank is neglected and a lumped system with uniform temperature is considered.

Considering the tank as an open system, the energy equation can be expressed as:

$$
\dot{\mathrm{Q}}-\dot{\mathrm{W}}+\dot{\mathrm{m}}_{\text {in }} \mathrm{h}_{\text {in }}-\dot{\mathrm{m}}_{\text {out }} \mathrm{h}_{\text {out }}=\frac{\mathrm{dU}}{\mathrm{dt}}
$$

Where $\dot{Q}$ includes all incoming and outgoing heat fluxes expressed as:

$$
\dot{\mathrm{Q}}=\mathrm{q}_{\mathrm{S}}-\mathrm{q}_{\text {cond }}-\mathrm{q}_{\text {conv }}-\mathrm{q}_{\text {sky }}
$$

Where $q_{s}$ is the absorbed solar energy by the tank surface with absorption coefficient, $\alpha$ and irradiating surface area of $A_{s}$ with solar radiation, $\mathrm{H}$, defined as:

$$
\mathrm{q}_{\mathrm{S}}=\alpha \times \mathrm{A}_{\mathrm{S}} \times \mathrm{H}
$$

$\mathrm{q}_{\text {cond }}$ is the amount of heat conducted to the foundation ground evaluated by Fourier's law of heat conduction:

$$
\mathrm{q}_{\text {cond }}=-\mathrm{kA}_{\mathrm{b}} \frac{\mathrm{dT}}{\mathrm{dx}}=\mathrm{kA}_{\mathrm{b}} \frac{\mathrm{T}_{\text {soil }}-\mathrm{T}_{\mathrm{S}}}{\Delta \mathrm{x}}
$$

Where $\Delta x, k$ and $T_{\text {soil }}$ are thickness, conductivity coefficient and temperature of foundation base with the area of $A_{b}$, respectively.

$q_{\text {conv }}$ evaluates the convective exchange of energy between the tank and the ambient:

$$
\mathrm{q}_{\text {conv }}=\mathrm{h} \mathrm{A}_{\mathrm{S}} \cdot\left(\mathrm{T}_{\mathrm{S}}-\mathrm{T}_{\infty}\right)
$$

In this study for calculating the convective heat transfer coefficient, h, the correlation proposed by Churchill and Bernstein 
[13] has been employed, which is valid for vertical cylinders, when $\operatorname{Re} . \operatorname{Pr}>0.2$ related to the present case and expressed as:

$$
\overline{\mathrm{N}} \mathrm{u}_{\mathrm{D}}=0.3+\frac{0.62 \operatorname{Re}_{\mathrm{D}}^{0.5} \cdot \operatorname{Pr}^{1 / 3}}{\left[1+\left(\frac{0.4}{\operatorname{Pr}}\right)^{2 / 3}\right]^{1 / 4}} \cdot\left[1+\left(\frac{\operatorname{Re}_{\mathrm{D}}}{282000}\right)^{5 / 8}\right]^{4 / 5}
$$

Radiation heat exchange between the sky and the tank can be obtained according to:

$$
\mathrm{q}_{\mathrm{sky}}=\sigma \cdot \varepsilon \cdot \mathrm{A}_{\mathrm{S}} \cdot\left(\mathrm{T}_{\mathrm{S}}^{4}-\mathrm{T}_{\mathrm{sky}}^{4}\right)
$$

Where $\mathrm{T}_{\text {sky }}$ is the sky temperature evaluated following Kamali and Moradi [12] as:

$$
\mathrm{T}_{\text {sky }}=0.0552 \times \mathrm{T}_{\infty}^{1.5}
$$

Exchange of energy has due to mass exchange including inlet and outlet mass transfer are the others term. As the displacement of the tank roof is negligible, the following assumption could be made:

$$
\dot{\mathrm{W}}=0 \quad \text { and } \quad \dot{\mathrm{m}}_{\text {in }} \dot{\mathrm{h}}_{\text {in }}=\dot{\mathrm{m}}_{\text {out }} \dot{\mathrm{h}}_{\text {out }}
$$

Exchange of energy by ambient causes change in internal energy which for crude oil could be expressed as below:

$$
\frac{\mathrm{dU}}{\mathrm{dt}}=\frac{\mathrm{d}}{\mathrm{dt}} \cdot\left(\mathrm{m}_{\mathrm{c}} \mathrm{c}_{\mathrm{p}} \mathrm{T}_{\mathrm{S}}\right)=\dot{\mathrm{m}} \cdot \mathrm{c}_{\mathrm{p}} \mathrm{T}_{\mathrm{S}}+\mathrm{m} \cdot \mathrm{c}_{\mathrm{p}} \cdot \frac{\mathrm{dT}}{\mathrm{dt}}
$$

Specific heat capacity is assumed function of oil (tank) temperature as follow

$$
\mathrm{C}_{\mathrm{P}}=4.348 \mathrm{~T}_{\mathrm{S}}+635.2
$$

Replacing equation [14] in [13], the below equation could be obtained: $\frac{\mathrm{d}}{\mathrm{dt}} \cdot\left(\mathrm{m}_{\mathrm{p}} \mathrm{c}_{\mathrm{p}} \mathrm{T}_{\mathrm{S}}\right)=\frac{\mathrm{d}}{\mathrm{dt}}\left(\mathrm{mT}_{\mathrm{S}}\left(4 \cdot 348 \mathrm{~T}_{\mathrm{S}}+635 \cdot 2\right)\right)=\dot{\mathrm{m}} \cdot \mathrm{c}_{\mathrm{p}} \mathrm{T}_{\mathrm{S}}+\mathrm{m} \cdot\left(4 \cdot 348 \frac{\mathrm{dT} \mathrm{T}_{\mathrm{S}}^{2}}{\mathrm{dt}}+635 \cdot 3 \frac{\mathrm{dT} \mathrm{S}}{\mathrm{dt}}\right)$

For simplicity, the quasi steady state condition has been assumed for the temperature time variation, therefore:

$$
\frac{\mathrm{dT}_{\mathrm{S}}}{\mathrm{dt}}=0 \quad \rightarrow \quad \frac{\mathrm{d}}{\mathrm{dt}} \cdot\left(\mathrm{m}_{\mathrm{m}} \mathrm{c}_{\mathrm{p}} \mathrm{T}_{\mathrm{S}}\right)=\text { m. } \mathrm{c}_{\mathrm{P}} \mathrm{T}_{\mathrm{S}}
$$

By substituting mentioned relations for each term and considering the assumptions, the energy equation will be formed as:

$$
\alpha H A_{S}+k A_{b} \frac{T_{\text {soil }}-T_{S}}{\Delta x}-h A_{S}\left(T_{S}-T_{\infty}\right)-\sigma \varepsilon A_{S}\left(T_{S}^{4}-T_{\text {sky }}^{4}\right)=\dot{m} \cdot c_{P} T_{S}
$$

By substituting equation 14 into energy equation, the following equation could be obtained:

$$
\begin{aligned}
& \alpha H A_{S}+k A_{b} \frac{T_{\text {soil }}-T_{S}}{\Delta x}-h A_{S}\left(T_{S}-T_{\infty}\right)-\sigma \varepsilon A_{S}\left(T_{S}^{4}-T_{\text {sky }}^{4}\right) \\
& =\dot{m} .\left(4.348 T_{S}+635.3\right) T_{S}
\end{aligned}
$$

Supposing $\mathrm{T}_{\text {soil }}=\mathrm{T}_{\infty}$ and arranging above relation, final form of energy equation could be written as follow:

$$
\begin{aligned}
& \sigma \varepsilon \mathrm{A}_{\mathrm{S}} \mathrm{T}_{\mathrm{S}}^{4}+4.348 \dot{\mathrm{m}} \mathrm{T}_{\mathrm{S}}^{2}+\left(\mathrm{h} \mathrm{A}_{\mathrm{S}}+\frac{\mathrm{kA_{b }}}{\Delta \mathrm{x}}+635.2 \dot{\mathrm{m}}\right) \\
& \times \mathrm{T}_{\mathrm{S}}-\left(\alpha H \mathrm{H}_{\mathrm{S}}+\mathrm{kA} \mathrm{A}_{\mathrm{b}} \frac{\mathrm{T}_{\infty}}{\Delta \mathrm{x}}+\mathrm{h} \mathrm{A}_{\mathrm{S}} \mathrm{T}_{\infty}+\sigma \varepsilon \mathrm{A}_{\mathrm{S}} \mathrm{T}_{\text {sky }}^{4}\right)=0
\end{aligned}
$$

There is one unknown in above equation, which is tank temperature that obtains from equation.

It worth mentioning that in API method $[14,15]$ a simple correlation has been proposed for computing monthly averaged tank temperature, which can also be used for estimating the monthly averaged evaporative losses:

$$
\mathrm{T}_{\mathrm{S}}=\mathrm{T}_{\infty}+1.86 \alpha+5 \times 10^{-5} \alpha \mathrm{H}-0.31
$$

\section{Estimating evaporation rate}

According to the API standards $[14,15]$ the total rates of evaporative losses from external floating roof tanks are equal to the sum of the rim seal losses, withdrawal losses, and deck fitting losses:

$$
\dot{\mathrm{m}}=\dot{\mathrm{m}}_{\mathrm{R}}+\dot{\mathrm{m}}_{\mathrm{WD}}+\dot{\mathrm{m}}_{\mathrm{F}}
$$

Rim seal loss from floating roof tanks can be estimated using the following equation:

$$
\dot{\mathrm{m}}_{\mathrm{R}}=2.5 \times 10^{-8} \times\left(\mathrm{k}_{\mathrm{Ra}}+\mathrm{k}_{\mathrm{Rb}} \mathrm{V}^{\mathrm{n}}\right) \mathrm{DP}^{*} \mathrm{M}_{\mathrm{V}} \mathrm{K}_{\mathrm{C}}
$$

Where $\mathrm{K}_{\mathrm{C}}$ is product factor and for crude oil is $0.4 . \mathrm{k}_{\mathrm{Ra}}, \mathrm{k}_{\mathrm{Rb}}$, $\mathrm{n}$ depended to kind of seal that being used. These parameters for khark island tanks are $0.7,0.3$ and 1.2 respectively. The vapor pressure, $P^{*}$, is evaluated according to:

$$
\mathrm{P}^{*}=\frac{\frac{\mathrm{P}_{\mathrm{VA}}}{\mathrm{P}_{\mathrm{A}}}}{\left[1+\left(1-\frac{\mathrm{P}_{\mathrm{VA}}}{\mathrm{P}_{\mathrm{A}}}\right)^{0.5}\right]^{2}}
$$

Where the true vapor pressure, $\mathrm{P}_{\mathrm{VA}}$, for selected petroleum at the stored liquid surface temperature can be determined using the following equation:

$$
\mathrm{P}_{\mathrm{VA}}=6.895 \times \exp \left[\mathrm{A}-\left(\frac{\mathrm{B}}{\mathrm{T}_{\mathrm{S}}}\right)\right]
$$

The constants $A$ and $B$ can be calculated from the following equations:

$$
\left\{\begin{array}{c}
A=12.82-0.9672 \operatorname{Ln}(\text { RVP }) \\
B=7261-1216 \times \operatorname{Ln}(\text { RVP })
\end{array}\right.
$$

Deck fitting losses from floating roof tanks can be estimated by the following equation:

$$
\dot{\mathrm{m}}_{\mathrm{R}}=2.5 \times 10^{-8} \mathrm{~F}_{\mathrm{F}} \mathrm{P}^{*} \mathrm{M}_{\mathrm{V}} \mathrm{K}_{\mathrm{C}}
$$

The value of $F_{F}$ is calculated using the actual tank-specific data for the number of each fit type $\left(\mathrm{N}_{\mathrm{Fi}}\right)$ multiplying by the fitting loss factor for each fitting $\left(\mathrm{K}_{\mathrm{Fi}}\right)$.

$$
\mathrm{F}_{\mathrm{F}}=\left[\left(\mathrm{N}_{\mathrm{F} 1} \mathrm{~K}_{\mathrm{F} 1}\right)+\left(\mathrm{N}_{\mathrm{F} 2} \mathrm{~K}_{\mathrm{F} 2}\right)+\ldots . .+\left(\mathrm{N}_{\mathrm{Fn}} \mathrm{K}_{\mathrm{Fn}}\right)\right]
$$

The deck fitting loss factor, $\mathrm{K}_{\mathrm{Fi}}$ for a particular type of fitting, can be estimated by the following equation:

$$
\mathrm{K}_{\mathrm{Fi}}=\mathrm{K}_{\mathrm{Fai}}+\mathrm{K}_{\mathrm{Fbi}}\left(\mathrm{K}_{\mathrm{V}} \mathrm{V}\right)^{\mathrm{mi}}(28)
$$

For external floating roof tanks, the fitting wind correction factor, $\mathrm{K}_{\mathrm{v}}$ is equal to 0.7 .

The withdrawal losses from floating roof storage tanks can be estimated using the following:

$$
\dot{\mathrm{m}}_{\mathrm{WD}}=2.829 \times 10^{-7} \times \frac{\mathrm{QC}_{\mathrm{S}} \mathrm{W}_{\mathrm{L}}}{\mathrm{D}}\left[1+\frac{\mathrm{N}_{\mathrm{C}} \mathrm{F}_{\mathrm{C}}}{\mathrm{D}}\right]
$$

Where $\mathrm{N}_{\mathrm{C}}$ is zero for the external floating roof.

\section{Results}

\section{Average crude oil temperature}

The experimental temperatures have been measured using infrared thermometer from roof surface of the storage tank for three days (on 7 December 2008, 25 February 2009 and 2 June 2009). The surface temperatures have been measured at various positions on the 


\begin{tabular}{|l|cc|c|c|}
\hline Date & Time & Experimental & Numerical Analysis \\
\hline 7 December 2008 & $9: 30$ & A.M. & $18.8^{\circ} \mathrm{C}$ & $19.51^{\circ} \mathrm{C}$ \\
\hline 7 December 2008 & $1: 30$ & P.M. & $21.2^{\circ} \mathrm{C}$ & $20.83^{\circ} \mathrm{C}$ \\
\hline 25 February 2009 & $8: 30$ & A.M. & $19.8^{\circ} \mathrm{C}$ & $20.49^{\circ} \mathrm{C}$ \\
\hline 25 February 2009 & $2: 30$ P.M. & $22.7^{\circ} \mathrm{C}$ & $21.49^{\circ} \mathrm{C}$ \\
\hline 2 June 2009 & $10: 30$ A.M. & $41.8^{\circ} \mathrm{C}$ & $40.13^{\circ} \mathrm{C}$ \\
\hline
\end{tabular}

Table 4: Comparison between the numerical predictions and the measured data of the tank temperature.

\begin{tabular}{|c|c|c|c|c|}
\hline \multirow{2}{*}{\multicolumn{2}{|c|}{$\begin{array}{l}\text { Tanks Construction \& Rim-seal } \\
\text { system }\end{array}$}} & \multicolumn{3}{|l|}{ Loss Factors } \\
\hline & & \multirow{2}{*}{$\begin{array}{l}\mathrm{K}_{\mathrm{Ra}} \text { (lb.mole/ft.yr) } \\
5.8\end{array}$} & \multirow{2}{*}{$\begin{array}{l}\mathrm{K}_{\mathrm{Rb}}(\mathrm{lb} . \mathrm{mole} / \\
\left.(\mathrm{mph})^{\mathrm{n}} . \mathrm{ft} . \mathrm{yr}\right)\end{array}$} & \multirow{2}{*}{$\begin{array}{l}n \\
2.1\end{array}$} \\
\hline \multirow{3}{*}{$\begin{array}{l}\text { Mechanical- } \\
\text { shoe seal }\end{array}$} & Primary only & & & \\
\hline & $\begin{array}{l}\text { Shoe-mounted } \\
\text { secondary }\end{array}$ & 1.6 & 0.3 & 1.6 \\
\hline & $\begin{array}{l}\text { Rim-mounted } \\
\text { secondary }\end{array}$ & 0.6 & 0.4 & 1.0 \\
\hline \multirow{3}{*}{$\begin{array}{l}\text { Liquid-mounted } \\
\text { seal }\end{array}$} & Primary only & 1.6 & 0.3 & 1.5 \\
\hline & Weather shield & 0.7 & 0.3 & 1.2 \\
\hline & $\begin{array}{l}\text { Rim-mounted } \\
\text { secondary }\end{array}$ & 0.3 & 0.6 & 0.3 \\
\hline \multirow{3}{*}{$\begin{array}{l}\text { Vapor-mounted } \\
\text { seal }\end{array}$} & Primary only & 6.7 & 0.2 & 3.0 \\
\hline & Weather shield & 3.3 & 0.1 & 3.0 \\
\hline & $\begin{array}{l}\text { Rim-mounted } \\
\text { secondary }\end{array}$ & 2.2 & 0.003 & 4.3 \\
\hline
\end{tabular}

Table 5: Rim seal loss factors for floating roof tanks.

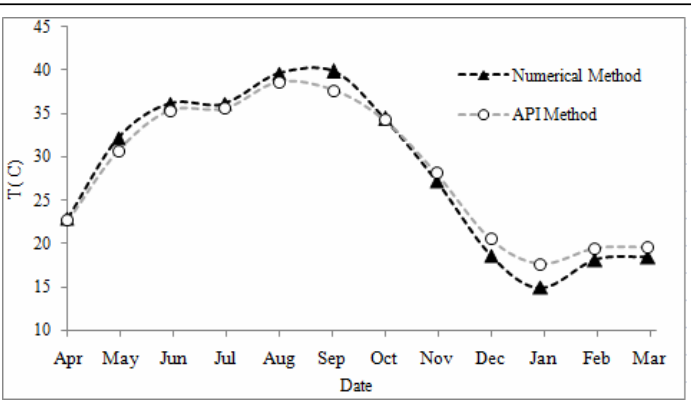

Figure 6: Comparison between API and numerical method of daily average tank temperature.

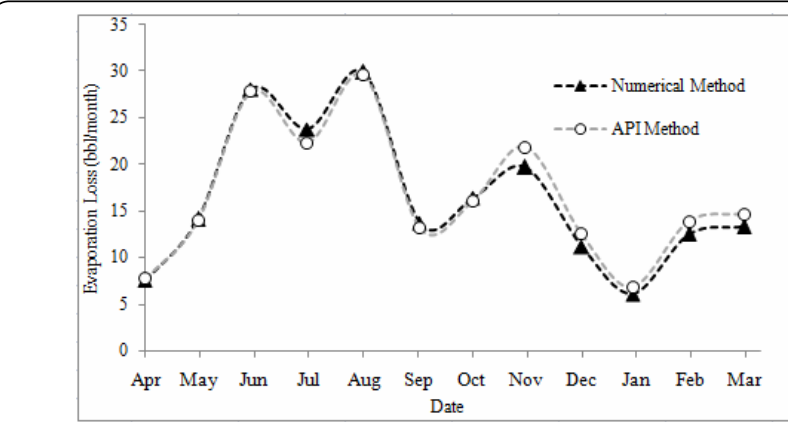

Figure 7: Total evaporation loss for each month

roof and the value which reported here is average one. The results of numerical method and experimental data for tank temperature are shown in (Table 4). As the surface is imposing to ambient condition (and solar radiation), the surface temperature is expected to be higher than average tank temperature especially at later of the day. This could be seen in results of (Table 4). But generally, the numerical results are in good agreement with measured values.

In addition of comparing measured and numerical values of transient temperature, the numerical results of average monthly tank temperatures have been also compared with similar value calculated from equation [20]. As stated previously, the equation [20] is proposed by API $[14,15]$. The comparison has been presented in (Figure 6). It could be seen that the numerical method predicts slightly higher and lower temperature during first and last 6 months of the year comparing to API proposed equation respectively. This is probably due to simplicity of equation [20] that did not consider the effects of other parameters such as wind speed in this equation.

\section{Evaporative loss}

Having examined the storage tank temperature, the evaporative losses from storage tanks can now be determined by the API method discussed earlier. (Figure 7) show monthly averaged evaporation loss for the tank under investigation in 2007. A comparison has been made between results obtained from numerical method and API [14, 15] method. Note from figure, the highest evaporations are occurred during June, July and August. This is due to the fact that these are hottest months in Khark Island. The peak in evaporation during November are due to high wind speed during period of time. Note from the figure, there are good agreement between the numerical results and API method.

Total losses from external floating roof tanks are summation of the rim seal loss, withdrawal loss and deck fitting loss. Each individual loss has been calculated and is shown in (Figure 8). Note from figure, the withdrawal loss in all month was equal, therefore this part of evaporation loss not changed with change of weather conditions, also this result could be obtain from equation [29]. (Figure 8) show that rim seal and deck fitting losses depended to climate conditions.

(Figure 9) show the percentage of annual evaporation loss from rim seal, deck fitting and withdrawal. Results of (Figure 9) show that maximum of evaporation loss happen from the deck fitting equal

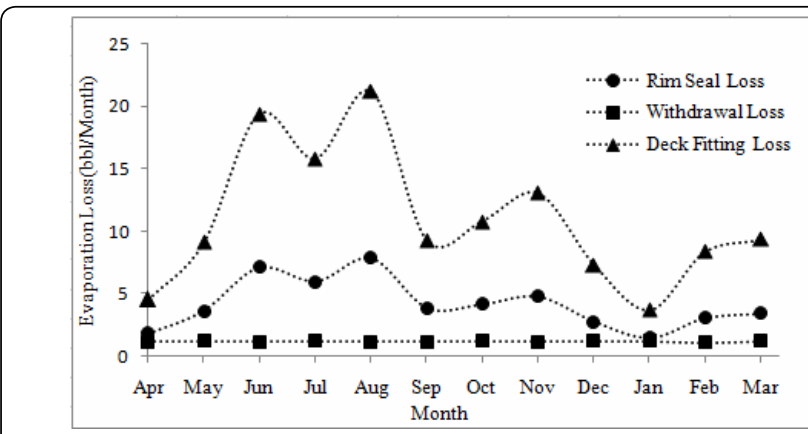

Figure 8: Each individual loss for all months.

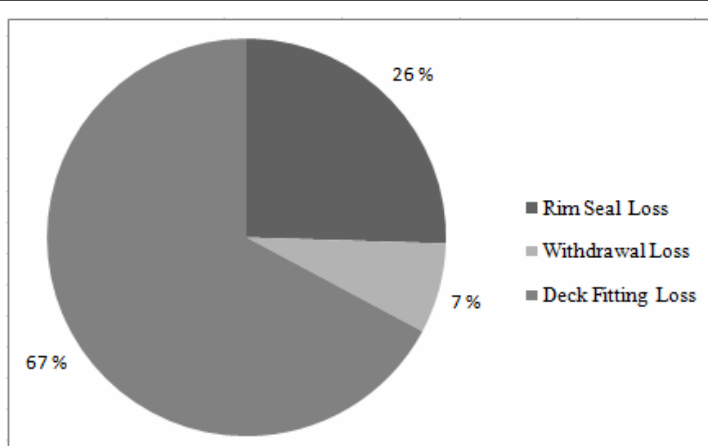

Figure 9: Percentage of annual loss from rim seal, deck fitting and withdrawal for storage tank. 


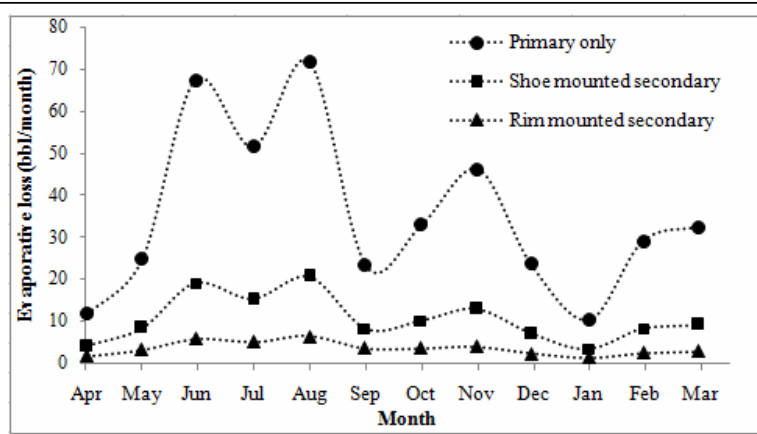

Figure 10: Evaporation loss from rim seal for mechanical shoe seal.

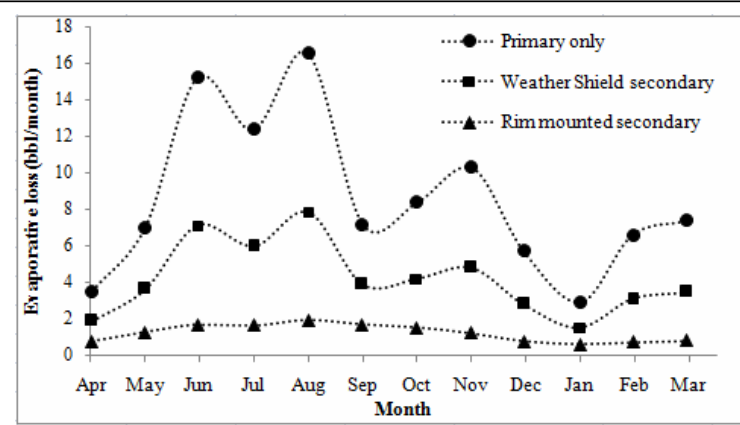

Figure 11: Evaporation loss from rim seal for liquid-mounted seal.

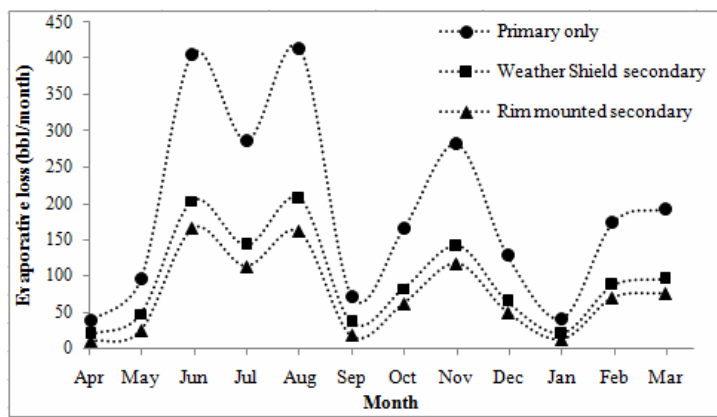

Figure 12: Evaporation loss from rim seal for vapor-mounted seal.

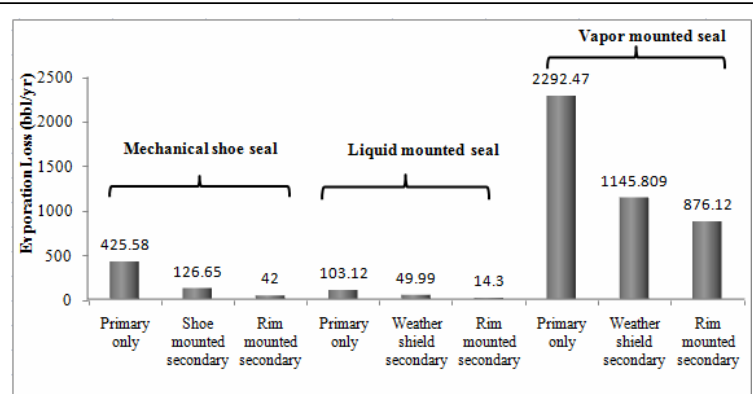

Figure 13: Annual evaporation loss from various type of sealing

$67 \%$ and minimum loss belong withdrawal loss equal $7 \%$, Therefore for decreasing total loss, deck fitting loss should be decreased, one solution for this problem is the replace poor gaskets of fitting with proper gaskets.

\section{Effect of rim seal on evaporation loss}

In equation [22] has been shown that evaporation loss has function of $\mathrm{k}_{\mathrm{Ra}}, \mathrm{k}_{\mathrm{Rb}}$ and $\mathrm{n}$, that these parameters depended to kind of seal that being used. These parameters for khark island tanks are 0.7, 0.3 and 1.2 respectively, because the primary seal that used for storage tanks is liquid mounted and the secondary seal is weather shield. The following nine type tank seal has been studied evaporation loss for each case has been calculated. In (Table 5) show, Rim seal loss factors for floating roof tanks [14,15].

Firstly, it is assumed that the mechanical shoe seal is primary seal and three types of secondary seal as: (1) no secondary seal (2) the shoe mounted secondary seal (3) the rim mounted secondary seal. Results of three cases are shown in (Figure 10).

Secondly, it is assumed that the liquid-mounted seal and three types of secondary seal as: (1) no secondary seal (2) the weather shield secondary seal (3) the rim mounted secondary seal. Results of three cases are shown in (Figure 11)

Finally, is assumed that the vapor-mounted seal and three types of secondary seal as: (1) no secondary seal (2) the weather shield secondary seal (3) the rim mounted secondary seal. Results of three cases are shown in (Figure 12).

As the type of sealing has a huge effect of the evaporation loss the annual evaporation loss from various seal types are compared and presented in (Figure 13).

The above results show that the losses are larger when the used vapor mounted seal for storage tank. In addition, combination primary and secondary seal drops the evaporation loss comparing with using primary seal only.

Liquid mounted as primary and rim-mounted as secondary is best combination in case of reducing evaporation lost.

\section{Conclusions}

One of the major difficulties related to crude oil storage tank, is evaporation loss. Light hydrocarbons vaporize in the space between the crude oil and the tank roof. This process affects the quality of the crude oil and causes environmental pollution.

In this study, a numerical scheme has been developed for estimating the time variations of the storage tank temperature and evaporative losses. The scheme is validated against the measured values of the storage tank temperature at different times during a day, where reasonable agreements are observed.

The numerical results of tank temperature have been compared with available experimental values and show a good agreement. The numerical value of monthly averaged evaporation loss which compared with the value of API AP-42 standard shows a good agreement too. These agreements are proved that the proposed numerical method is able to predict the tank temperature and the evaporation loss accurately.

The results show that maximum losses are occurred in June, July and August. This is due to high solar radiation and wind speed respectively. Considering these facts, for reducing the losses, the effects of wind speed and solar radiation on the tanks should be reduced. These could be done by using wind obstruct wall and thermal insulations.

The withdrawal loss not changed with change of weather conditions, but rim seal and deck fitting losses depended to climate conditions. Maximum of evaporation loss happen from the deck fitting equal $131.3 \mathrm{bbl} / \mathrm{yr}$ and minimum loss belong withdrawal loss equal $13.7 \mathrm{bbl} / \mathrm{yr}$. 
Citation: Gord MF, Nabati A, Targhi MS, Rasekh A (2010) Effect of Rim Seal on Evaporation Loss from Khark Island Storage Tanks. J Pet Environ Biotechnol 1:103. doi:10.4172/2157-7463.1000103

Page 7 of 7

Comparing the results for primary seal show that liquid mounted seal has lowest the evaporation loss among all three primary seals which are available.

The results show that the losses are larger when the used vapor mounted seal/primary only for storage tank with $2292 \mathrm{bbl} / \mathrm{yr}$ and liquid mounted as primary and rim-mounted as secondary is best combination have lowest evaporation loss with $14 \mathrm{bbl} / \mathrm{yr}$.

In addition, combination primary and secondary seal drops the evaporation loss comparing with using primary seal only.

Finally, it should be noted that selecting better seal for storage tanks lead to decreasing evaporation loss, reducing environment pollution and has economical advantages.

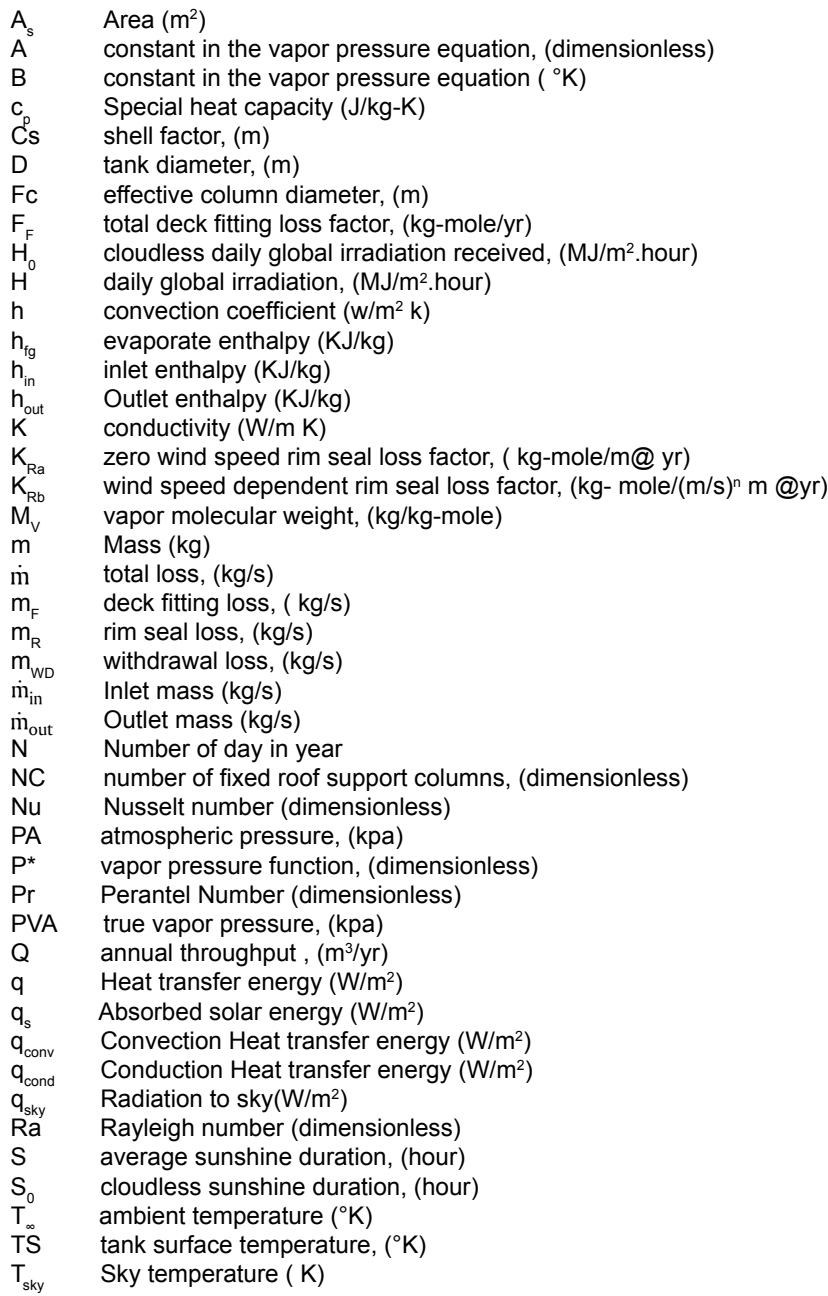

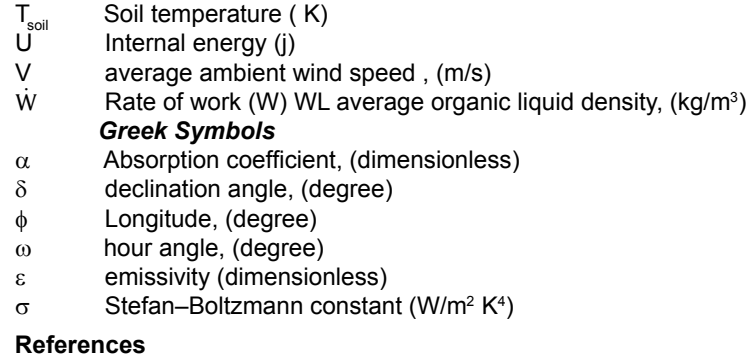

1. Abdel-Aal HK, Aggour M, Fahim M (2003) Petroleum and gas field processing In: Chapter 8- Storage Tanks and Other Field Facilities. New York: Marce Dekker Inc: $\mathrm{p} 1$.

2. Laverman RJ (1992) Emission Reduction Options for Floating Roof Tanks. Second International Symposium on Aboveground Storage Tanks, Houston.

3. Ramachandran S (2000) Reducing (controlling) vapour losses from storage tanks. 7th annual India Oil \& Gas Review, Symposium \& International Exhibition, Bombay, (IORS)

4. Michael C (2006) Emission Factor Documentation for AP-42 Section 7.1 Organic Liquid Storage Tanks. In: Chapter 2- Storage Tank Descriptions, U S Environmental Protection Agency; p. 1-5.

5. Wongwises S, Rattanaprayura I, Chanchaona S (1997) An Evaluation of Evaporative Emissions of Gasoline from Storage Sites and Service Stations. Thailand Thammasat Int. J Sc Tech. Vol 2 No 2.

6. Asharif H, Zorgani E (2007) Adjustment of Process Variables to Reduce Evaporation Losses from High pour point-crude oil storage tanks. The 8th international conference on petroleum phase behavior and fouling, France.

7. Digrado BD, Gregory AT (2004) The aboveground steel storage tank handbook In: chapter 13: new field-erected aboveground storage tank products. New Jersey: John Wiley \& Sons Inc; p. 127.

8. API (1989) Evaporative Loss from External Floating Roof Tanks. Bulletin No 2517, Third Edition, American Petroleum Institute, Washington, DC.

9. API (1990) Evaporative Loss from Internal Floating Roof Tanks.API Publication 2519, American Petroleum Institute, Washington, DC.

10. Zareie S, Mowla D, Fathi J (2007) Practical Study of VOCs Emission from External Floating Roof Tanks. 5th international congress of chemical engineering, Shiraz, Iran

11. Sen Z (2008) Solar Energy Fundamentals and Modeling Techniques. Londen: Springer Veriag. p. 47-140.

12. Kamali GA, Moradi E (2005) Solar radiation fundamentals and application in farms and new energy. Tehran: publication 21 century.

13. Churchill SW, Bernstein MA (1977) Correlating Equation for Forced Convection from Gases and Liquids to a Circular Cylinder in Cross Flow. J Heat Transfer p.300-306.

14. API (1994) Manual of Petroleum Measurement Standards. In: Chapter 19 Evaporative Loss Measurement, Section 2- Evaporative Loss From Floating Roof Tanks. Preliminary Draft, American Petroleum Institute, Washington DC.

15. Michael C (2006) Emission Factor Documentation for AP-42 Section 7.1 Organic Liquid Storage Tanks. In: Chapter 3-Emission Estimation Procedure. U S Environmental Protection Agency. p 9-11: 15-18. 